\title{
The Effect of Planned Training Regarding Breast Self-Examination on Women's Health Beliefs
}

\section{Kendi Kendine Meme Muayenesi ile İlgili Verilen Planlı Eğitimin Kadınların Sağlık İnançlarına Etkisi}

\author{
(1) Özlem Duran Aksoy', @ Mustafa Ferit Koçoğlu² \\ 1 Department of Midwifery, Faculty of Health Sciences, Sivas Cumhuriyet University, Sivas, Turkey \\ ${ }^{2}$ Department of Public Health, Faculty of Medicine, Sivas Cumhuriyet University, Sivas, Turkey
}

\begin{abstract}
Aim: This study was conducted quasi-experimentally to determine the effect of planned training regarding breast self-examination on women's health beliefs.

Material and Method: The research group consisted of 108 women from the Semi-Open Women's Prison, the Public Training Center, and the Evening Art School and from the Quran Course in the Family Health Center region. Data were collected using a sociodemographic characteristics questionnaire and the Turkish version of the Champion's Health Belief Model Scale. A control group was not used in this study; women's before the training evaluations were used as a control for their evaluations eight weeks after the training.

Results: In this study, it was determined that $32.4 \%$ of the women had training on breast self-examination and knew to perform breast self-examination. For the recent year, $15.7 \%$ of the women have performed breast self-examination, $10.2 \%$ have had a clinical breast examination and $10.4 \%$ have had mammography. After the training, it was determined that there was a significant positive increase in the perceptions of susceptibility, seriousness, benefit, confidence and health motivation subscales of the Champion's Health Belief Model Scale. In addition, the perception of barriers declined significantly in a positive direction $(p<0.05)$.

Conclusion: It was determined that the rate of women performing breast self-examination and having a mammogram was low and that there was a significant increase in the Champion's Health Belief Model Scale subscales after the training compared to before the training evaluations. It is recommended that midwives and nurses should consider the health beliefs of women in breast examination training and prepare their training programs accordingly.
\end{abstract}

Keywords: Breast self-examination, health belief model, midwife, nurse, training

\section{Öz}

Amaç: Araştırma, kadınlara kendi kendine meme muayenesi ile ilgili verilen planlı eğitimin sağlık inançlarına etkisini belirlemek amacıyla yarı deneysel olarak yapılmış̧ır.

Gereç ve Yöntem: Araştırma grubunu, Yarı Açık Kadın Cezaevi'nde bulunan Halk Eğitim Merkezi ve Akşam Sanat Okulu'ndan seçilen ile Aile Sağlığı Merkezi Bölgesi'ndeki Kur'an kursuna devam eden kadınlar olmak üzere toplam 108 kadın oluşturmuştur. Araştırmanın verileri, kadınlara yönelik sosyo-demografik soru formu ve Türkçe Champion'un Sağlık Innanç Modeli Ölçeği ile toplanmıştır. Araşıırmada kontrol grubu kullanılmamış, kadınların eğitim verilmeden önceki değerlendirmeleri, eğitimden sekiz hafta sonraki değerlendirmelerinin kontrolü olarak alınmışıır.

Bulgular: Araşıırmada, kadınların \%32.4'ünün kendi kendine meme muayenesi eğitimi aldığı ve kendi kendine meme muayenesi yapmayı bildiği saptanmıştır. Son bir yıl içerisinde kadınların \%15.7'sinin kendi kendine meme muayenesi yaptığı, \%10.2'sinin klinik meme muayenesi yaptırdığı ve \%10.4'ünün ise mamografi çektirdiği bulunmuştur. Eğitim faaliyeti sonrasında, Champion'un Sağlık Inanç Modeli Ölçeği alt boyutlarından olan duyarlıık, ciddiyet, yarar, güven ve sağlık motivasyonu algılarında olumlu yönde anlamlı bir artı̧̧ olduğu saptanırken, engel algısının da olumlu yönde değişerek önemli ölçüde azaldığı belirlenmiştir $(p<0.05)$.

Sonuç: Kadınların kendi kendine meme muayenesi yapma ve mamografi çektirme oranlarının düşük düzeyde olduğu, eğitim öncesi değerlendirmelere göre eğitim sonrasında Champion'un Sağlık Innanç Modeli Ölçeği alt boyutlarında olumlu yönde anlamlı bir artış olduğu belirlenmiştir. Ebe ve hemşirelerin meme muayenesi ile ilgili eğitimlerde kadınların sağlık inançlarıı göz önünde bulundurmaları ve eğitim programlarını bu doğrultuda hazırlanmaları önerilmektedir.

Anahtar Sözcükler: Kendi kendine meme muayenesi, sağlık inanç modeli, ebe, hemşire, eğitim

Corresponding (IIletişim): Özlem Duran Aksoy, Sivas Cumhuriyet University, Faculty of Health Sciences, Department of Midwifery, 58140, Sivas, Turkey

E-mail (E-posta): ozlemeliha@gmail.com, oduran@cumhuriyet.edu.tr

Received (Geliş Tarihi): 21.02.2020 Accepted (Kabul Tarihi): 21.07.2020 


\section{INTRODUCTION}

Breast cancer is one of the most common cancers diagnosed in women in Turkey and in the world. In our country, 24.8\% of cancers diagnosed in women constitute breast cancer. ${ }^{[1-3]}$ Early diagnosis and treatment of breast cancer are effective in prolonging the life span, in reducing mortality and in increasing quality of life. ${ }^{[4]}$ The main methods recommended for early diagnosis are breast self-examination (BSE), clinical breast examination (CBE) and mammography. ${ }^{[5]}$

Breast self-examination is a method that does not require the use of any tools, is cheap, advantageous and can be routinely applied effectively by the woman herself. It is stated that there will be an opportunity to identify some signs with BSE that may indicate breast cancer due to masses detected in the breast. ${ }^{[6]}$ However, studies show that women do not have enough knowledge about breast cancer prevention. ${ }^{[6-8]}$ In previous studies, while the knowledge of women regarding BSE is between $8-80 \%,{ }^{[6,7,9-17]}$ their rate of performing monthly regular BSE ranges between 6-22\%. ${ }^{[7,9,11-13,16,17]}$ In our country, $19.7 \%$ of women aged 15 and over perform monthly BSE. ${ }^{[1]}$

Various interventions have been developed to increase the rates of BSE screening in Turkish women. These interventions include training programs organized by midwives and nurses, training initiatives with written materials, mass media and training activities. Although it is not clear which of these initiatives is strategically effective, the need for further education is clear. ${ }^{[18]}$ Although randomized controlled trials have reported that BSE is not effective in early diagnosis in recent years, many organizations indicate that BSE is an important screening method for increasing women's awareness. ${ }^{[19]}$ According to the "National Standards for Breast Cancer Screening Program" in Turkey, while the main screening method is for women aged 40-69 years to have a mammogram every two years, it is recommended that women participating in screening also perform CBE in order to increase the effectiveness of mammography. In addition, counseling services are provided for women to perform BSE after the age of 20 to raise awareness in society. Breast cancer screening is carried out by Cancer Early Diagnosis, Screening and Training Centers within the Family Health Centers (FHC) and Community Health Centers. ${ }^{[20]}$ Although BSE alone has a limited effect in reducing the mortality of breast cancer, BSE has an important place for early detection of breast cancer in developing countries, ${ }^{[19]}$ such as Turkey, where rates of women having regular mammograms are low (9\%). ${ }^{[1]}$ At the same time, since there is a relationship between women having CBE and having BSE on a regular basis, it is recommended to teach BSE by linking with other diagnostic methods and to reinforce the information provided. ${ }^{[21]}$

Providing early detection of breast cancer depends on increasing the awareness of breast cancer. ${ }^{[3]}$ The Health Belief Model (HBM) created in this framework has been designed by adding cognitive-perceptual variables such as control perception, self-efficacy perception, health definition, and health perception that affect the decision-making process for behavior formation. ${ }^{[22]}$ In these studies, HBM is used in training and evaluations about BSE and breast health screening behaviors of women are tried to be based on more solid foundations. ${ }^{[23-29]}$ Situations that prevent breast health protection behaviors, perceived susceptibility to disease, and health motivations are described. When these studies are examined, it is seen that the educational contents are specific for breast cancer and BSE. It is thought that, besides $\mathrm{BSE}$, the content and use of different teaching techniques can positively affect the attitudes and behaviors of women regarding the BSE. The findings obtained will be important while planning training and in evaluations regarding BSE. The aim of this study was to determine the effect of the planned training regarding BSE on women's health beliefs.

\section{Research Questions}

- What is the level of breast cancer screening practices of women in the recent year before training?

- Does the planned training given to women about breast self-examination have an impact on their health beliefs?

\section{MATERIAL AND METHOD}

\section{Design}

This study was conducted quasi-experimentally based on a single group with a pretest-posttest design.

\section{Participants}

The population of the study consisted of women from the Semi-Open Women's Prison (39), the Public Training Center and the Evening Art School (37), and the Quran Course in Family Health Center region (49) of one province in Central Anatolia in Turkey. The institutions included in the study were selected considering the obstacles women faced in accessing health services, and considering women's socioeconomic and educational status because they represented each level. The number of women in the Semi-Open Women's Prison has been taken into consideration in the formation of the research group. The research group consisted of 108 women from the Semi-Open Women's Prison (31 participants; 8 could not attend the final evaluation because they had been released from prison), the Public Training Center and the Evening Art School (36 participants; 1 could not be reached for the final evaluation) and from the Quran Course in the Family Health Center region (41 participants; final evaluation could not be made for 8 participants who did not attend the course). 17 out of 125 participants were not included in the study as the final evaluation could not be made. In our study, $a=0.05$ was taken for the sample group of 108, the power of the study was found to be 0.99 as a result of the power analysis calculated based on 0.50 effect size which was obtained using the mean and standard deviation values of the group before and after the training.

\section{Inclusion Criteria}

Women who were at least primary school graduates, had no breast cancer, were not involved in pregnancy and lactation processes and agreed to participate in the study were included. 


\section{Exclusion Criteria}

Women who had breast cancer, were involved in pregnancy and lactation processes were not included in the study.

\section{Instruments}

\section{Women's Sociodemographic Characteristics Questionnaire}

The questionnaire was developed by researchers and consisted of a total 33 questions, namely, 10 questions assessing the descriptive characteristics of the women (such as age, marital status, educational status, occupation, and social security status), 13 questions about their risk for developing breast cancer, and 10 questions assessing their information, practice and information resources for breast cancer diagnosis.

\section{Champion's Health Belief Model Scale (CHBMS)}

The scale was designed by Champion in 1984 to determine women's beliefs and attitudes about breast cancer and BSE and revised in his later studies. In this study, the scale adapted to Turkish by Karayurt and Dramali was used. In the scale, there are 6 subscales which are "susceptibility", "seriousness", "benefits", "barriers", "confidence/self-efficacy" and "health motivation". The five-point likert-type scale format was used to measure responses. "strongly agree" was scored as five, "agree" as four, "undecided" as three, "disagree" as four and "strongly disagree" as one, separately. A single total score was not calculated. In the adaptation study, the scale's time invariance was assessed by test-retest correlation and was found to be between 0.89 and 0.99 for all subscales. The Cronbach Alpha reliability coefficients ranged from 0.58 to 0.89 for the subscales. ${ }^{[30]}$ In this study, the Cronbach Alpha coefficient value for the subscales ranged from 0.58 to 0.86 .

\section{Intervention}

On the first day of the intervention, the women were informed about the topic of the research, its importance and benefits, and the written consents of the women who agreed to participate in the study were obtained.

On the second day of the intervention, women were asked to fill out the sociodemographic characteristics questionnaire by measuring their body weight and height.

On the third day of the intervention, women were informed about their Body Mass Index (BMI) values, which were calculated using the body weights and heights of the women, the CHBMS was filled out, and the training date was decided.

In planning the training, the advice of two training specialists (educational psychology specialist in the field of educational sciences) was taken. The training consisted of two parts: drama and narration, and demonstration. The training was carried out by the first researcher as a group training. The researcher attended the "Training of the Trainer in Breast Cancer" course before planning the training. It was ensured that the groups had a minimum of 15 and a maximum of 21 people.

On the fourth day of the intervention, training using the drama method was carried out in 5 stages. The first stage, i.e., the warm up stage, consisted of breathing exercises; walking exercises; and neck, shoulder, waist, wrist and leg movements. In the second stage, i.e., the inclusion stage, "who am I", "let's know the hospital", or one of the bingo games were used to allow the group members to get to know each other. In the third stage, the activity part, two prepared breast cancer stories were shared with the group and turned into a drama. In the fourth stage, the feelings part, achievements and experiences of the group members in the drama process were evaluated. In the last stage, the group was relaxed with physical relaxation and recreational techniques.

On the fifth day of the intervention, the narration and demonstration sections of the training were completed. After the discussion of health and disease concepts with women, a presentation consisting of the structure of the breast, the incidence of breast cancer, the factors causing breast cancer, the types of breast cancer, signs and symptoms of breast cancer and prevention from breast cancer was made. In the demonstration part of the training, demonstrations were made on breast models according to BSE steps and they were carried out until all the women could do it properly. After the training, the brochure prepared by the Turkey Breast Foundation and the "American Cancer Society Breast Cancer Screening Guideline" were distributed to all women.

The final assessment of the CHBMS was made 8 weeks after the training on the sixth day of the intervention.

\section{Data Collection}

Data of the study were collected between April 2 and June 26, 2008 with the sociodemographic characteristics questionnaire and the Turkish version of the Champion's Health Belief Model Scale. The questionnaires were completed by the face-to-face interviewing method and took 15-20 minutes, on average.

\section{Ethical Considerations}

To collect the data, ethical approval (Decision No. 2007-10/2) was obtained from the Ethics Committee of Sivas Cumhuriyet University Faculty of Medicine; approval was also obtained from the institutions in which the study was conducted. The study was conducted in accordance with the Declaration of Helsinki. The women who were approached for participation in the study were informed that the decision about participating in the study was completely their own, that no name would be written on the questionnaire form and that the data obtained from the study would only be used within the scope of the research. It was stated that the collected information would be confidential, identifying information was not requested, and participation was voluntary. Written consents were obtained from those who agreed to participate in the study.

\section{Data Analysis}

The analysis of the data was done using the Statistical Package for the Social Sciences version 22.0 program in a computer environment. The percentage tests were used in the evaluation of the data and the Kolmogorov-Smirnov test was used in determining the normality of the data distribution. The data obtained from the CHBMS were seen to be normally distributed. A paired t test was used in the evaluation of the scale when the research group used before the training evaluations as a control for after the training evaluations. The data were assessed with $95 \%$ confidence intervals and using a 0.05 significance level. 


\section{RESULTS}

The mean age of the 108 women in the study was $34.4 \pm 11.7$. It was determined that $67.6 \%$ of the women in the study were 40 years old below, $61.1 \%$ were married, $51.9 \%$ were primary school graduates, $91.7 \%$ did not work, $77.8 \%$ had social security and $55.6 \%$ perceived their financial situation as moderate level. When the women in the study group were evaluated in terms of some breast cancer risk factors, $83.3 \%$ of them had menarche at the age of 13 and over, $98.7 \%$ of them had their first birth at the age of 30 and below, $14.8 \%$ of them went through menopause, $71.3 \%$ of them had children, 92.2\% breastfed their children, $8.3 \%$ had breast cancer history in their family, $22.2 \%$ smoked, $4.6 \%$ consumed alcohol, and $45.4 \%$ were obese (Table $\mathbf{1}$ ).

\begin{tabular}{|c|c|c|c|c|c|c|c|c|}
\hline \multirow{2}{*}{ Characteristics } & \multicolumn{2}{|c|}{ Prison $(n=31)$} & \multicolumn{2}{|c|}{ PTC $(n=36)$} & \multicolumn{2}{|c|}{ FHC $(n=41)$} & \multicolumn{2}{|c|}{ Total $(n=108)$} \\
\hline & $\mathbf{n}$ & $\%$ & $\mathbf{n}$ & $\%$ & $\mathbf{n}$ & $\%$ & $\mathbf{n}$ & $\%$ \\
\hline \multicolumn{9}{|l|}{ Age $($ Mean $=34.4 \pm 11.7)$} \\
\hline 29 and below & 11 & 35.5 & 22 & 61.1 & 8 & 19.5 & 41 & 38.0 \\
\hline $30-39$ & 14 & 45.2 & 2 & 5.6 & 16 & 39.0 & 32 & 29.6 \\
\hline $40-49$ & 5 & 16.1 & 7 & 19.4 & 9 & 22.0 & 21 & 19.4 \\
\hline 50 and above & 1 & 3.2 & 5 & 13.9 & 8 & 19.5 & 14 & 13.0 \\
\hline \multicolumn{9}{|l|}{ Marital status } \\
\hline Married & 15 & 48.4 & 17 & 47.2 & 34 & 82.9 & 66 & 61.1 \\
\hline Single & 16 & 51.6 & 19 & 52.8 & 7 & 17.1 & 42 & 38.9 \\
\hline \multicolumn{9}{|l|}{ Educational status } \\
\hline Primary school & 19 & 61.3 & 9 & 25.0 & 28 & 68.3 & 56 & 51.9 \\
\hline Secondary school & 8 & 25.8 & 12 & 33.3 & 7 & 17.1 & 27 & 25.0 \\
\hline High school and above & 4 & 12.9 & 15 & 41.7 & 6 & 14.6 & 25 & 23.1 \\
\hline \multicolumn{9}{|l|}{ Employment status } \\
\hline Working & 5 & 16.1 & 3 & 8.3 & 1 & 2.4 & 9 & 8.3 \\
\hline Not working & 26 & 83.9 & 33 & 91.7 & 40 & 97.6 & 99 & 91.7 \\
\hline \multicolumn{9}{|l|}{ Social security } \\
\hline Yes & 9 & 29.0 & 35 & 97.2 & 40 & 97.6 & 84 & 77.8 \\
\hline No & 22 & 71.0 & 1 & 2.8 & 1 & 2.4 & 24 & 22.2 \\
\hline \multicolumn{9}{|l|}{ Perceived monthly income } \\
\hline Good & 8 & 25.8 & 13 & 36.1 & 7 & 17.1 & 28 & 25.9 \\
\hline Moderate & 10 & 32.3 & 20 & 55.6 & 30 & 73.1 & 60 & 55.6 \\
\hline Bad & 13 & 41.9 & 3 & 8.3 & 4 & 9.8 & 20 & 18.5 \\
\hline \multicolumn{9}{|l|}{ Age of menarche } \\
\hline 12 and $\downarrow$ & 7 & 22.6 & 6 & 16.7 & 5 & 12.2 & 18 & 16.7 \\
\hline 13 and $\uparrow$ & 24 & 77.4 & 30 & 83.3 & 36 & 87.8 & 90 & 83.3 \\
\hline \multicolumn{9}{|l|}{ Age of first birth $(n=77)$} \\
\hline 30 and $\downarrow$ & 27 & 100.0 & 14 & 93.3 & 35 & 100.0 & 76 & 98.7 \\
\hline 31 and $\uparrow$ & 0 & 0.0 & 1 & 6.7 & 0 & 0.0 & 1 & 1.3 \\
\hline \multicolumn{9}{|l|}{ Going through menopause } \\
\hline Yes & 1 & 3.2 & 6 & 16.7 & 9 & 22.0 & 16 & 14.8 \\
\hline No & 30 & 96.8 & 30 & 83.3 & 32 & 78.0 & 92 & 85.2 \\
\hline \multicolumn{9}{|l|}{ Breastfeeding $(n=77)$} \\
\hline Yes & 22 & 81.5 & 15 & 100.0 & 34 & 97.1 & 71 & 92.2 \\
\hline No & 5 & 18.5 & 0 & 0.0 & 1 & 2.9 & 6 & 7.8 \\
\hline \multicolumn{9}{|c|}{ Breast cancer history in the family } \\
\hline Yes & 1 & 3.2 & 1 & 2.8 & 7 & 17.1 & 9 & 8.3 \\
\hline No & 30 & 96.8 & 35 & 97.2 & 34 & 82.9 & 99 & 91.7 \\
\hline \multicolumn{9}{|l|}{ Smoking } \\
\hline Yes & 20 & 64.5 & 3 & 8.3 & 1 & 2.4 & 24 & 22.2 \\
\hline No & 11 & 35.5 & 33 & 91.7 & 40 & 97.6 & 84 & 77.8 \\
\hline \multicolumn{9}{|l|}{ Consuming alcohol } \\
\hline Yes & 4 & 12.9 & 1 & 2.8 & 0 & 0.0 & 5 & 4.6 \\
\hline No & 27 & 87.1 & 35 & 97.2 & 41 & 100.0 & 103 & 95.4 \\
\hline \multicolumn{9}{|l|}{ Body mass index } \\
\hline Thin & 0 & 0.0 & 2 & 5.6 & 0 & 0.0 & 2 & 1.8 \\
\hline Normal & 11 & 35.5 & 16 & 44.4 & 4 & 9.8 & 31 & 28.7 \\
\hline Little fat & 8 & 25.8 & 6 & 16.7 & 12 & 29.2 & 26 & 24.1 \\
\hline Obese & 12 & 38.7 & 12 & 33.3 & 25 & 61.0 & 49 & 45.4 \\
\hline
\end{tabular}


It was determined that $32.4 \%$ of the women had already had BSE training and $67.6 \%$ had not had training (Table 2); $54.3 \%$ were informed by health professionals and $36.7 \%$ were informed by media and written materials.

Table 2. Prior BSE training according to groups of women $(n=108)$

\begin{tabular}{lcccccccc} 
Prior BSE & \multicolumn{2}{c}{ Prison $(\mathbf{n = 3 1 )}$} & \multicolumn{2}{c}{ PTC $(\mathbf{n}=\mathbf{3 6})$} & \multicolumn{2}{c}{ FHC $(\mathbf{n = 4 1 )}$} & \multicolumn{2}{c}{ Total $(\mathbf{n = 1 0 8 )}$} \\
\cline { 2 - 9 } Training & $\mathbf{n}$ & $\%$ & $\mathbf{n}$ & $\%$ & $\mathbf{n}$ & $\%$ & $\mathbf{n}$ & $\%$ \\
\hline Yes & 16 & 51.6 & 12 & 33.3 & 7 & 17.1 & 35 & 32.4 \\
No & 15 & 48.4 & 24 & 66.7 & 34 & 82.9 & 73 & 67.6 \\
\hline
\end{tabular}

BSE: Breast Self-Examination, PTC: Public Training Center, FHC: Family Health Center

When we look at women's BSE performance, which is one of the behaviors related to early diagnosis, it is seen that $15.7 \%$ of the women performed BSE in the recent year and $84.3 \%$ did not. It is seen that $82.4 \%$ performed BSE once a year and $17.6 \%$ of them did so twice a year. When the women's behaviors related to the early diagnosis of breast cancer was examined within the recent year, $10.2 \%$ had a CBE, and $10.4 \%$ had a mammogram (Table 3).

A significant positive increase was seen in the susceptibility, seriousness, benefit, confidence and health motivation subscales after the training $(p<0.05)$. At the end of the training, the perceived barrier subscale changed positively by decreased significantly ( $p<0.05$, Table 4$)$.

Table 4. Distribution of the women's CHBMS subscale mean scores before and after training $(\mathrm{n}=108)$

\begin{tabular}{lcccc} 
& \multicolumn{2}{c}{ Mean Score } & \multicolumn{2}{c}{ Test Value } \\
\cline { 2 - 5 } CHBMS Subscales & $\begin{array}{c}\text { Before } \\
\text { Mean } \pm \text { SD }\end{array}$ & $\begin{array}{c}\text { After } \\
\text { Mean } \pm \text { SD }\end{array}$ & t & p \\
\hline Susceptibility & $7.67 \pm 2.19$ & $9.39 \pm 1.46$ & 9.08 & $0.001^{*}$ \\
Seriousness & $20.70 \pm 6.15$ & $24.72 \pm 4.26$ & 6.66 & $0.001^{*}$ \\
Benefit & $17.47 \pm 4.50$ & $21.02 \pm 2.20$ & 8.25 & $0.001^{*}$ \\
Barrier & $29.08 \pm 6.85$ & $21.57 \pm 3.69$ & 11.73 & $0.001^{*}$ \\
Confidence & $30.70 \pm 7.87$ & $40.20 \pm 3.60$ & 12.82 & $0.001^{*}$ \\
Health Motivation & $23.45 \pm 6.36$ & $26.96 \pm 3.46$ & 5.96 & $0.001^{*}$ \\
\hline CHBMS: Champion's Health Belief Model Scale, SD: Standard deviation, t: Paired T test, ${ }^{*}$ Significant
\end{tabular}

\section{DISCUSSION}

The American Cancer Society reports that women should be aware of changes in their breasts. ${ }^{[31]}$ Although BSE alone has a limited effect in reducing the mortality of breast cancer, BSE has an important place for early detection of breast cancer in developing countries, such as Turkey, where the rates of women having regular mammograms are low. ${ }^{[19]}$ In the current study, $32.4 \%$ of the women were found to have prior BSE training and knew how to do a BSE (Table 2). When the BSE information sources were examined, it was seen that $54.3 \%$ of women were informed by health professionals and $36.7 \%$ were informed by the media and written materials. In previous studies, women's knowledge of BSE varied between $8-80 \% \cdot{ }^{[6,7,9-17]}$ Although the results obtained from the research are in line with the results of many studies, the rate of women receiving $B S E$ training was quite low. This is thought to be due to the inadequacy of training and awareness-raising activities. In the studies conducted in terms of information sources, the rate of being informed by the media and written materials is between $16 \%$ and $62 \%$, and the rate of being informed by health professionals is between $2 \%$ and $46 \%$. $[9-11,14,16,17,23]$ In the vast majority of these studies, the main source of information about BSE is the media and written materials, and the secondary source is health professionals. In this study, receiving information from health professionals is dominant. This is thought to be due to the training of healthcare professionals and, especially in the prison group, due to the high availability of information. At the same time, the proportion of women in prison who have access to media and written materials is also low.

When we look at the women's BSE performance, which is one of the behaviors related to early diagnosis, it was determined that $15.7 \%$ of the women performed a BSE in the last year and $84.3 \%$ did not. It was seen that $82.4 \%$ of the women performed BSE once a year and $17.6 \%$ of them twice a year (Table 3). In similar studies, while $8-28 \%$ of women performed $\mathrm{BSE},{ }^{[6,10,14-17]}$ only $6-22 \%$ of them performed it once a month

Table 3. Breast cancer screening practices in the recent year before the training according to groups of women $(n=108)$

\begin{tabular}{|c|c|c|c|c|c|c|c|c|}
\hline \multirow{2}{*}{ Variables } & \multicolumn{2}{|c|}{ Prison $(n=31)$} & \multicolumn{2}{|c|}{ PTC $(n=36)$} & \multicolumn{2}{|c|}{ FHC $(n=41)$} & \multicolumn{2}{|c|}{ Total $(n=108)$} \\
\hline & $\mathbf{n}$ & $\%$ & $\mathbf{n}$ & $\%$ & $\mathbf{n}$ & $\%$ & $\mathbf{n}$ & $\%$ \\
\hline \multicolumn{9}{|l|}{ Performed BSE } \\
\hline Yes & 6 & 19.4 & 6 & 16.7 & 5 & 12.2 & 17 & 15.7 \\
\hline \multicolumn{9}{|c|}{ BSE frequency $(n=17)$} \\
\hline Once a year & 5 & 83.3 & 5 & 83.3 & 4 & 80.0 & 14 & 82.4 \\
\hline Yes & 3 & 9.7 & 3 & 8.3 & 5 & 12.2 & 11 & 10.2 \\
\hline No & 28 & 90.3 & 33 & 91.7 & 36 & 87.8 & 97 & 89.8 \\
\hline \multicolumn{9}{|c|}{ Reported mammography* $(n=67)$} \\
\hline Yes & 1 & 5.0 & 3 & 21.4 & 3 & 9.1 & 7 & 10.4 \\
\hline No & 19 & 95.0 & 11 & 78.6 & 30 & 90.9 & 60 & 89.6 \\
\hline
\end{tabular}


on a regular basis. ${ }^{[7,9,11-13,16,17]}$ The rate obtained in this study is lower than the values in other studies. It is also interesting that women did not perform BSE even though they know how to do it. A wide range of interventions has been implemented to promote breast cancer screening behaviors in Turkish women. These include training with breast models, use of audiovisual materials, and oral training sessions. ${ }^{[24]}$ Although these training methods have effects on information, their effects on awareness are not clear. The result of the current research is thought to be related to the fact that the aim is only to provide information and not to raise awareness. In addition, women's beliefs about BSE may not be taken into consideration during the information process.

When the women's behaviors toward early diagnosis of breast cancer within the recent year were examined, it was seen that $10.2 \%$ had a CBE and $10.4 \%$ had a mammogram (Table 3). In previous studies, it was seen that $8-49 \%$ of women had a CBE and 5-54\% had a mammogram. [9,11,12,16,29,32-34] The rate of women having CBE was low and similar to that found in previous studies. It was seen that the rate of having mammography was low compared to other studies. The fact that both early diagnosis methods are used when women have complaints rather than for screening may be influential in the emergence of this result. In our country, it is thought that women may have experienced obstacles due to lack of information, neglect, lack of necessity, anxiety, lack of interest, shame and financial problems that impact their access to CBE and mammography.

In this study, the effect of the training on the subscales of the CHBMS was investigated after evaluating BSE training and early diagnosis methods in breast cancer. A significant positive increase was seen in the perception of susceptibility subscale and seriousness subscale mean scores after the BSE training (Table 4, $\mathrm{p}<0.05$ ). In previous studies, there was a significant increase in women's perception of susceptibility to breast cancer after BSE training. . $17,24,26,28,34-38]$ In the current study, giving the training to at least 15 and at most 21 people with drama, narration and demonstration methods is likely to have affected our results. However, the process of dramarelated narration may have brought women closer to the idea of breast cancer and increased their susceptibility scores. In previous studies, there was a significant increase in women's perception of seriousness after the BSE training; $[17,24,26,29,34-36]$ the findings of these studies support the result of this study. It is thought that women putting themselves in place of the patients during the drama method caused empathy and the story evaluations caused an increase in the perception of seriousness.

While a significant positive increase was seen in the perception of benefit subscale mean score after the training, the perceived barrier subscale mean score decreased significantly (Table 4, $p<0.05$ ). In previous studies, there was a significant increase in women's perception of benefit after BSE training. $[17,24-26,28,29,35-37,39]$ The findings of this study are consistent with those of previous studies. In the method of narration used in training, it is thought that informing the women about the benefits of BSE has a positive effect on the result. In previous studies, a significant decrease was seen in the women's perceived barrier subscale after the BSE training. ${ }^{[17,26,28,29,35,36,39]}$ In a study conducted by Masoudiyekta et al. ${ }^{[24]}$ a significant increase was found in the women's perceived barrier subscale after the training. The findings of this study are consistent with the findings of previous studies. It is thought that the repetition of the BSE until the correct technique was used during the demonstration method, and the information given on the importance of BSE in early detection of breast cancer during narration method affect the results positively. At the same time, as demonstrated by Açıkgöz et al. ${ }^{[9]}$ giving positive feedback to women and changing their perception regarding BSE (such as lack of information, negligence and not believing in the necessity) in our country may also be effective in reducing the perception of barriers.

The perception of confidence and health perception subscales mean scores increased significantly after the BSE training (Table 4, $\mathrm{p}<0.05$ ). When previous studies were evaluated, a significant increase was seen in the perception of confidence after the BSE training. ${ }^{[17,24,26,28,29,35-37,39]}$ Previous studies support the result of this study. One-to-one training sessions with the demonstration method, $\mathrm{CBE}$ administration to women during the research process, informing women about how to seek help from institutions in case of risk and cooperation with health professionals are all thought to be influential on the increase in the perception of confidence. In previous studies, a significant increase was seen in women's perception of health motivation after BSE. ${ }^{[17,24,26,28,29,34-36]}$ The result of this study is consistent with previous studies. This result is thought to be due to information given to assess women's risk factors prior to training to protect against breast cancer and for calculation of their BMI. In addition, it may be due to healthrelated interventions that do not affect a single aspect of the individual because they concern the whole.

\section{CONCLUSION}

It was determined that the rates of women performing $\mathrm{BSE}$, having a CBE and having mammograms was low, and there was a significant increase in the CHBMS subscales after the training compared to before the training evaluations. It is recommended that midwives and nurses should consider the health beliefs of women in breast examination training and prepare their training programs accordingly. In the implementation of this recommendation, it is very important to share the current information and practices in the literature whose effectiveness has been determined in order to increase the awareness of women about their health beliefs and breast examination with health professionals working in the provision of primary healthcare through in-service trainings. The aim of the training sessions on breast examination in primary 
health care services in our country is not only to provide information but also to raise awareness. Giving BSE training sessions together with other diagnostic methods used in the early diagnosis of breast cancer, using different teaching techniques in education (drama, narration, demonstration, etc.), effectively repeating the breast examination with women until the correct BSE technique is learned, and periodic followups are recommended for the elimination of obstacles to breast examination and other early diagnosis methods.

Limitations: The research groups in the study were related to each other and were similar in terms of age and working status. However, as the results of the study cannot represent all of the women in the FHC region and the Public Education Center, they cannot be generalized. The results obtained from women in prison will not represent women in other prisons.

\section{ETHICAL DECLARATIONS}

Ethics Committee Approval: To collect the data, ethical approval (Decision No. 2007-10/2) was obtained from the Ethics Committee of Sivas Cumhuriyet University Faculty of Medicine.

Informed Consent: All patients signed the free and informed consent form.

Referee Evaluation Process: Externally peer-reviewed.

Conflict of Interest Statement: The authors have no conflicts of interest to declare.

Financial Disclosure: This study was supported by Sivas Cumhuriyet University Scientific Research Projects Commission (T-369 Doctoral Thesis Project).

Author Contributions: All of the authors declare that they have all participated in the design, execution, and analysis of the paper, and that they have approved the final version.

Disclaimer: This study was presented in the form of poster presentation XIII. National Public Health Congress.

Acknowledgements: The authors thank all of the women who agreed to participate in this study. They also would like to thank the managers and employees of the institutions in which the study was conducted for their cooperation.

\section{REFERENCES}

1. Bora Başara B, Soytutan Çağlar I, Aygün A, Özdemir TA. Republic of Turkey Ministry of Health, Health Statistics Yearbook 2018. Ankara: Republic of Turkey Ministry of Health General Directorate of Health Research, 2019.

2. Ferlay J, Soerjomataram I, Dikshit R, et al. Cancer incidence and mortality worldwide: sources, methods and major patterns in GLOBOCAN 2012. Int J Cancer 2015;136(5):E359-E386.

3. Global Burden of Disease Cancer Collaboration, Fitzmaurice C, Allen C, et al. Global, Regional, and National Cancer Incidence, Mortality, Years of Life Lost, Years Lived With Disability, and Disability-Adjusted Life-years for 32 Cancer Groups, 1990 to 2015: A Systematic Analysis for the Global Burden of Disease Study. JAMA Oncol 2017;3(4):524-48.

4. Ersin F, Bahar Z. Effects of health promotion models on breast cancer early detection behaviors: a literature review. Dokuz Eylül Üniversitesi Hemşirelik Yüksekokulu Elektronik Derg 2012;5(1):28-38.
5. Rawashdeh M, Zaitoun M, McEntee MF, et al. Knowledge, attitude and practice regarding clinical and self breast examination among radiology professionals. Breast Cancer Manag 2019;7(3):BMT16. doi: 10.2217/bmt2018-0014.

6. Baliga MS, Rao S, Rao $P$, et al. Knowledge of cancer and self-breast examination among women working in agricultural sector in Mangalore, Karnataka, India. IJAR 2017;3(7):200- 2.

7. Kaushal N, Kumari N, Pallavi PK et al. A descriptive study to assess the knowledge, attitude and practice regarding breast cancer and breast selfexamination among women in selected area, Shimla (Himachal Pradesh). IJAR 2017;3(9):29-31.

8. Kohler RE, Gopal S, Lee CN, Weiner BJ, Reeve BB, Wheeler SB. Breast Cancer Knowledge, Behaviors, and Preferences in Malawi: Implications for Early Detection Interventions From a Discrete Choice Experiment. J Glob Oncol 2017;3(5):480-9.

9. Açıkgöz A, Çehreli R, Ellidokuz $H$. Determination of knowledge and behavior of women working at a hospital on breast cancer early detection methods, and investigation of efficiency of planned education. J Breast Health 2015;11:31-8.

10. Alpteker H, Avcı A. Determine the knowledge of the women about breast cancer and their practice about breast self examination. J Breast Health 2010;6(2):74-9.

11. Sohbet R, Karasu F. Investigation of the knowledge, behavior and applications of their women towards breast cancer. Gümüşhane University Journal of Health Sciences 2017;6(4):113-21.

12. Hajian-Tilaki K, Auladi S. Health belief model and practice of breast self-examination and breast cancer screening in Iranian women. Breast Cancer 2014;21:429-34.

13. Karahan N. Prevalence and determinants of breast self-examination in Karabuk, Turkey. Cukurova Medical Journal 2019;44(3):1046-54. doi: 10.17826/cumj.492127.

14. Sapkota D, Parajuli P, Kafle TK. Effectiveness of educational intervention programme on knowledge regarding breast self examination among higher secondary school girls of Biratnagar. Birat Journal of Health Sciences 2016;1(1):13-9.

15. Singh $R$, Turuk A. A study to assess the knowledge regarding breast cancer and practices of breast self-examination among women in urban area. IJCMPH 2017;4(11):4341-7.

16. Veena KS, Kollipaka R, Rekha R. The knowledge and attitude of breast self examination and mammography among rural women. Int J Reprod Contracept Obstet Gynecol 2015;4(5):1511-6.

17. Karasu F, Göllüce $A$, Güvenç $E$, et al. The effectiveness of training given about breast cancer in a foundation university students. Mersin University Journal of Health Sciences 2017;10(1):14-24.

18. Secginli S, Nahcivan NO, Gunes G, Fernandez R. Interventions promoting breast cancer screening among Turkish women with global implications: a systematic review. Worldv Evid-Based Nu 2017;14(4):316-23.

19. Akyolcu N, Uğraş GA. Breast self-examination: How important is it in early diagnosis?. J Breast Health 2011;7(1):10-4.

20. TR Ministry of Health. National Standards for Breast Cancer Screening Program. Ankara: Republic of Turkey Ministry of Health Directorate of Public Health Department of Cancer; 2018. .[Cited 17 Dec 2018] Available from: https://hsgm.saglik.gov.tr/tr/kanser-taramastandartlari/listesi/485-meme-kanseri-tarama-program\%C4\%B1-ulusalstandartlar\%C4\%B1.html.

21. Amoran OE, Toyobo OO. Predictors of breast self-examination as cancer prevention practice among women of reproductive age-group in a rural town in Nigeria. Niger Med J 2015;56(3):185-9.

22. Pender NJ. Health Promotion in Nursing Practice. 2nd ed. Norwalk, CT: Appleton \& Lange, 1987.

23. Abolfotouh MA, BaniMustafa AA, Mahfouz AA, Al-Assiri MH, Al-Juhani AF, Alaskar AS. Using the health belief model to predict breast self examination among Saudi women. BMC Public Health 2015;15:1163-75.

24. Masoudiyekta L, Rezaei-Bayatiyani H, Dashtbozorgi B, Gheibizadeh M, Malehi AS, Moradi M. Effect of Education Based on Health Belief Model on the Behavior of Breast Cancer Screening in Women. Asia Pac J Oncol Nurs 2018;5(1):114-20. 
25. Ouyang $Y Q, H u X$. The effect of breast cancer health education on the knowledge, attitudes, and practice: a community health center catchment area. J Cancer Educ 2014;29(2):375-81.

26. Rezaeian M, Sharifirad G, Mostafavi F, Moodi M, Abbasi MH. The effects of breast cancer educational intervention on knowledge and health beliefs of women 40 years and older, Isfahan, Iran. J Educ Health Promot 2014;3:43.

27. Ceber E, Turk M, Ciceklioglu M. The effects of an educational program on knowledge of breast cancer, early detection practices and health beliefs of nurses and midwives. J Clin Nurs 2010;19:2363-71.

28. Ersin F, Bahar Z. Effects of nursing interventions planned with the health promotion models on the breast and cervical cancer early detection behaviors of the women. IJCS 2017;10(1):421-32.

29. Gözüm S, Karayurt O, Kav S, Platin N. Effectiveness of peer education for breast cancer screening and health beliefs in eastern Turkey. Cancer Nurs 2010;33(3):213-20.

30. Karayurt O, Dramali A. Adaptation of Champion's Health Belief Model Scale for Turkish women and evaluation of the selected variables associated with breast self-examination. Cancer Nurs 2007;30(1):69-77.

31. American Cancer Society. Breast Cancer Facts \& Figures 2017-2018. Atlanta: American Cancer Society, 2017.

32. Al-Zalabani AH, Alharbi KD, Fallatah NI, Alqabshawi Rl, Al-Zalabani AA, Alghamdi SM. Breast Cancer Knowledge and Screening Practice and Barriers Among Women in Madinah, Saudi Arabia. J Cancer Educ 2018;33(1):201-7.

33. Türk R, Eroğlu K, Terzioğlu F, Taşkın L. An example from the rural areas of Turkey: Women breast cancer risk levels and application and knowledge regarding early diagnosis-scan of breast cancer. J Breast Health 2017; 13:67-73.

34. Mermer G, Turk M. Assessment of the effects of breast cancer training on women between the ages of 50 and 70 in Kemalpasa, Turkey. Asian Pac J Cancer Prev 2014;15(24):10749-55.

35. Kartal A, Inci FH, Koştu N, Çınar IÖ. Effect of individual training given to women in the home environment on health beliefs for breast selfexamination. Pamukkale Medical Journal 2017;1:7-13. doi: 10.5505/ ptd.2017.35651

36. Mahmoud MH, Sayed SH, Ibrahim HAF, Abd-Elhakam EM. Effect of health belief model-based educational intervention about breast cancer on nursing students' knowledge, health beliefs and breast self-examination practice. IJSN 2018;3(3):77-90.

37. Secginli S, Nahcivan NO. The effectiveness of a nurse-delivered breast health promotion program on breast cancer screening behaviours in non-adherent Turkish women: a randomized controlled trial. IJSN 2011;48:24-36.

38. Nahidi F, Dolatian M, Roozbeh N, Asadi Z, Shakeri N. Effect of healthbelief-model-based training on performance of women in breast selfexamination. Electron Physician 2017;9(6):4577-83.

39. Rokhforouz F, Nasirzadeh M, Asadpour M. The effect of educational intervention based on trans-theoretical model on the correct behavior of breast self-examination among health volunteers in Rafsanjan City, Iran. J Adv Med Biomed Res 2019;27(121):32-9. doi: 10.30699/jambs.27.121.32. 